\title{
DERIVATIVES AND BANKRUPTCY: THE FLAWED CASE FOR SPECIAL TREATMENT
}

\section{Stephen J. Lubben*}

The casual reader of recent scholarship on the treatment of contracts in chapter 11 could easily suppose that the Bankruptcy Code is the source of great injustices and inefficiencies. ${ }^{1}$ According to the standard account, chapter 11 locks third parties into inefficient contracts while allowing the debtor to "cherry pick" which contracts it wants to perform. ${ }^{2}$ Cherry picking is deemed "bad," for reasons that are generally rather vague. ${ }^{3}$

The putative scourge of cherry picking provides the foundation for the Bankruptcy Code's special treatment of derivative contracts, ${ }^{4}$ which are not

*Daniel J. Moore Professor of Law, Seton Hall University School of Law. Many thanks to Stephanie Ben-Ishai, Kristen Boon, R. Michael Farquhar, Adam Levitin, Andrew Shaffer, David Skeel, Charles Sullivan, Tracey Kaye, and Elizabeth Warren for helpful comments on earlier drafts.

1. E.g., Alan Schwartz, A Normative Theory of Business Bankruptcy, 91 VA. L. REV. 1199 (2005) (arguing that a bankruptcy law focused on capital cost reduction would be much smaller and less centralized than current law).

2. Id. at 1232. Apparently cherries are the fruit of choice when discussing contracts and bankruptcy; this paper will adhere to the convention. E.g., Rhett G. Campbell, Energy Future and Forward Contracts, Safe Harbors and the Bankruptcy Code, 78 AM. BankR. L.J. 1, 44 (2004) (discussing the debtors' ability to assume or reject certain trade provisions based on their financial advantage); Roberta Romano, A Thumbnail Sketch of Derivative Securities and Their Regulation, 55 MD. L. REV. 1, 54 (1996)(discussing creditors' normal procedure of picking only those outstanding swaps which provide a net-positive value to the debtor company); Adam R. Waldman, OTC Derivatives \& Systemic Risk: Innovative Finance Or The Dance Into The Abyss?, 43 AM. U. L. Rev. 1023, 1059-60 (1994) (discussing the ability of an administrator or trustee for the insolvent counterparty to cherry pick profitable contracts and refuse to honor unprofitable ones).

3. Cf. John C. Dugan, Derivatives: Netting, Insolvency, and End Users, 112 BANKING L.J. 638, 640 (1995) (explaining that bankruptcy can entail legal risks such as cherrypicking).

4. Financial derivatives are contracts that derive their value from interest rates, the outcome of specific events, or the price of underlying assets such as debt or equities. Franklin Allen, Richard A. Brealey \& Stewart C. Myers, Principles of Corporate FinANCE 727 (8th ed. 2006). Well known examples include options, futures, and forwards. Id. See Stephen J. Lubben, Credit Derivatives and the Future of Chapter 11, 82 AM. BANKR. L.J. 77 (2008); infra Part III. See also Stephen J. Lubben, Credit Derivatives and the Resolution Of Financial Distress, in The Credit DeRIVATIVes HandBook (Greg N. 
subject to the automatic stay ${ }^{5}$ or the Bankruptcy Code's normal rules prohibiting termination solely as a result of one party's bankruptcy filing. ${ }^{6}$ Alternatively, some argue that the special treatment of derivatives is justified because "derivatives contracts are generally not firm-specific assets and therefore giving them special treatment will increase economic efficiency." ${ }^{7}$

The first argument, although finding some support in a few loosely reasoned opinions, ${ }^{8}$ misconstrues the executory contract provisions of the Bankruptcy Code and ignores the fact that parties can always "cherry pick" which contracts to perform outside of bankruptcy: this is the well recognized "option to breach" embedded in every contract. ${ }^{9}$ Moreover, the second argument, while initially more convincing, falters once we consider that the vast bulk of firms that seek relief under chapter 11 are not financial firms. ${ }^{10}$ Rather, these debtors are operating companies or groups that use derivatives as insurance against the risks faced in the course of their business: that is, they use derivatives as hedges, rather than for speculation. ${ }^{11}$ A derivative used as a hedge is an integral part of the going concern value of the business. ${ }^{12}$

Does this mean that the case for the special treatment of derivatives is fatally flawed? No. But the case is inherently weak. ${ }^{13}$ The best argument

Gregoriou \& Paul U. Ali eds., McGraw-Hill 2008).

5. 11 U.S.C. § 362.

6. See Shmuel Vasser, Derivatives in Bankruptcy, 60 Bus. LAW 1507, 1510 (2005) (discussing how the Bankruptcy Code sometimes limits normal bankruptcy procedures in cases of alleged systemic risk).

7. Frank R. Edwards \& Edward R. Morrison, Derivatives and the Bankruptcy Code: Why the Special Treatment?, 22 YALE J. ON REG. 92, 94 (2005).

8. E.g., In re Kmart Corp., 359 F.3d 866, 873 (7th Cir. 2004) (asserting by citation to section 362 itself that the "automatic stay prevents [parties under contract] from walking away").

9. The option to breach concept has been recognized in both the law and economics discussions of "efficient breach," RICHARD POSNER, ECONOMIC ANALYSIS OF THE LAW 133 (5th ed. 1998), and more broadly, in Legal Realist conceptions of contract. See Jay Westbrook, A Functional Analysis of Executory Contracts, 74 MinN. L. REV. 227, 231 (1989) (“'Assume' and 'reject' are merely bankruptcy terms for the decision to perform or to breach, an election open to any party to a contract outside of bankruptcy”).

10. Of the 734 debtors in Lynn LoPucki's database http://www.lopucki.com, only 38 appear to have finance related operations.

11. Christine Hurt, Regulating Public Morals and Private Markets: Online Securities Trading, Internet Gambling, and the Speculation Paradox, 86 B.U. L. REV. 371, 385-86 (2006).

12. See Justin Baer, Southwest Airlines' fuel hedging boosts profits, Fin. TIMES, July 25, 2008, at 14-15 (explaining that Southwest's derivatives are valued at $\$ 4.3$ billion and cover 80 percent of the company's fuel bill and 70 percent of 2009's expected costs).

13. Perhaps it is fatally weak when considered in conjunction with Edwards \& Morrison's convincing argument that excluding derivatives from the bankruptcy process increases the risks of contagion in the financial system. Edwards \& Morrison, supra note 7, 
for excusing derivatives from the normal rules of chapter 11 turns on uncertainty. In particular, given the number of bankruptcy judges presiding over cases in the United States and the myriad backgrounds of these judges, predicting the treatment of complicated financial contracts upon a future bankruptcy filing would be quite difficult. This uncertainty might have detrimental (i.e., inefficient) effects on the larger derivatives markets, which has importance well beyond the world of bankruptcy. ${ }^{14}$

The weakness of this latter argument lays in its general applicability: every counterparty to a contract likely fears how it will be treated in bankruptcy. ${ }^{15}$ Moreover, the argument is in fact less powerful with regard to derivative contracts, inasmuch as chapter 11 cases involving derivative transactions have a high probability of being filed in but a handful of jurisdictions, ${ }^{16}$ and the calculation of breach damages is likely more transparent than it would be in connection with other contracts. ${ }^{17}$ That is, derivatives are less likely than other contracts to be subject to the full range of possible outcomes that result from the diversity in the bankruptcy bench and counterparties to these contracts can thus better estimate the likely result upon default. The policy reasons for offering derivatives special treatment remain vague. ${ }^{18}$

This is not to say that the delay associated with chapter 11 is costless. Rather, the question is why derivative counterparties should not have to endure this cost like every other creditor.

The cost imposed by chapter 11 is a cost imposed on all unsecured creditors, resulting from a plausible policy judgment that the collective gains from the reorganization process exceed the sum of these costs. The special treatment of derivative contracts is just one more example of the

at 103-04. For purposes of this article, I place this argument to the side, although it clearly must figure in any broader analysis of the special treatment of derivatives in bankruptcy.

14. See generally Edward R. Morrison \& Joerg Riegel, Financial Contracts And The New Bankruptcy Code: Insulating Markets From Bankrupt Debtors And Bankruptcy Judges, 13 Am. BANKR. Inst. L. REV. 641 (2005) (making a similar argument).

15. Cf. Edwards \& Morrison, supra note 7, at 98-99 (noting that the safe harbors cover too many and too few contracts).

16. See Lynn M. LoPucki \& Sara D. Kalin, The Failure of Public Company Bankruptcies in Delaware and New York: Evidence of a "Race to the Bottom", 54 VAND. L. REv. 231, 232 (2001) (explaining that Delaware had become the lead jurisdiction of choice in which to file bankruptcy in the early 1990's); Robert K. Rasmussen \& Randall S. Thomas, Timing Matters: Promoting Forum Shopping by Insolvent Corporations, 94 Nw. U. L. REV. 1357, 1360 (2000) (observing that publically traded companies prefer to file chapter 11 in New York and Delaware); see also Stephen J. Lubben, Delaware's Irrelevance, 16 AM. BANKR. INST. L. REV. 267, 270 (2008) (stating that Delaware was a lead choice for large chapter 11 cases).

17. I will concede that the damages are potentially more volatile in the derivatives context, subject to change on a daily or even hourly basis, but this does not seem to change whether the derivatives are inside or outside the bankruptcy process.

18. However, the public choice explanation for the special treatment appears obvious 
increasing tendency for special interest legislation to erode the efficiency of chapter 11 by piecemeal repeal of the chapter. ${ }^{19}$ At some point, this trend could completely undermine the collective process that is chapter 11 .

$* * *$

After a brief review of the Bankruptcy Code's assumption and rejection provisions, and the provisions that provide special treatment to derivatives, I address the key issues in order. First, I show how the Bankruptcy Code's provisions regarding the assumption and rejection of contracts are unremarkable in a world where parties always retain an option to breach. To be sure, in bankruptcy breach damages will most often be under-compensated, as the debtor is insolvent. But this fact is exogenous to either chapter 11 or the Bankruptcy Code - insolvency is a risk regardless of the presence or absence of any given bankruptcy system. ${ }^{20}$ The Bankruptcy Code adds one unique element-its prohibition on termination solely because of the bankruptcy filing - but I show how this simply prevents inefficient breaches based on extraneous factors, such as spite or fear of the bankruptcy system. Given this understanding of the Bankruptcy Code, the special treatment of derivatives appears increasingly suspect.

I then address the argument that the special treatment can be rationalized as a recognition that derivative contracts are assets that do not contribute to the debtor's going concern value. After a brief overview of the most common forms of derivatives, I demonstrate how this argument fails in the case of derivatives used for hedging and illustrate the point with examples from several annual reports. I also illuminate the simple point that the Bankruptcy Code is unique in treating all derivatives alike, while other areas of law, notably the Tax Code, expressly recognize the importance of the hedging versus speculation distinction when addressing the treatment of derivatives.

In this final section of the paper I also concentrate on the implications of these conclusions: in particular, does this analysis argue for the complete repeal of the Bankruptcy Code's special derivative provisions? I think not. ${ }^{21}$ Instead, I argue that these provisions should continue to apply

19. See generally Richard Levin \& Alesia Ranney-Marinelli, The Creeping Repeal Of Chapter 11: The Significant Business Provisions Of The Bankruptcy Abuse Prevention And Consumer Protection Act Of 2005, 79 AM. BANKR. L.J. 603 (2005) (arguing that special interest lobbying has lead to Bankruptcy Code changes that adversely affect the ability of businesses to reorganize).

20. One could argue that breaches of real estate leases and employment contracts are under-compensated as a result of sections 502(b)(6) and (7) which cap these claims. I view these provisions as providing protection against shirking of the duty to mitigate, although clearly there is an unanswered (and perhaps unanswerable) empirical question lurking behind my assumption.

21. This answer is, of course, somewhat dependent on the narrow focus of the paper. 
in chapter 7 cases. Moreover, they should presumptively apply in chapter 11 cases involving financial firms, which are more likely to involve speculative derivatives, where argument about the lack of going concern value has the most salience. ${ }^{22}$ In chapter 11 cases involving non-financial debtors, the special derivative provisions should be presumptively inapplicable, subject to a showing that the derivatives in question are in fact speculative.

\section{AsSUMPTION, REJECTION, AND DERIVATIVES}

Upon a chapter 11 filing, an "estate" is created comprised of virtually every asset in which the debtor holds a legal or equitable interest as of the petition date, as well as the proceeds, rents or profits from those assets. ${ }^{23}$ In addition, the continued stability of this estate is ensured by the automatic stay, which halts creditor efforts to gain control of estate assets. ${ }^{24}$

The debtor's contracts and leases begin bankruptcy with one foot in the estate and one foot out. ${ }^{25}$

Specifically, because section 362(b) of the Bankruptcy Code, which provides a list of exceptions to the automatic stay, does not mention termination of contracts with the debtor, several courts have held that nondebtor parties are precluded from unilaterally terminating a contract or lease with the debtor, absent relief from the automatic stay. ${ }^{26}$ Why this should be so, especially in cases where the contract would be terminable outside of bankruptcy, is unclear. Arguably the automatic stay should not

See supra note 13 .

22. Of course, many of these firms may be forced into chapter 7 , depending on their corporate structure. See 11 U.S.C. § 109(d) (excluding corporations that are not organized under section 25A of the Federal Reserve Act and operate, or operate as, a multilateral clearing organization pursuant to section 409 of the Federal Deposit Insurance Corporation Improvement Act of 1991 from being a debtor under chapter 11).

23. 11 U.S.C. $\S 541$.

24. 11 U.S.C. § 362(a).

25. In re Drexel Burnham Lambert Group, Inc., 138 B.R. 687, 700-01 (Bankr. S.D.N.Y. 1992).

26. E.g., In re Computer Comnc'ns, 824 F.2d 725, 728-31 (9th Cir. 1987) (holding that non-debtor violated the automatic stay statute by terminating its contract unilaterally); In re El Paso Refinery, L.P., 220 B.R. 37, 43-44 (Bankr. W.D. Tex. 1998) (stating that pending assumption or rejection of the estate, the non-debtor party to an executor contract is bound by terms of the contract); Edwards Mobile Home Sales, Inc. v. Ohio Casualty Ins. Co. (In re Edwards Mobile Home Sales, Inc.), 119 B.R. 857, 860 (Bankr. M.D. Fla. 1990) (finding that non-debtor may not terminate contract without first obtaining relief from the automatic stay); see also Douglas W. Bordewieck, The Postpetition, Pre-Rejection, Pre-Assumption Status of an Executory Contract, 59 AM. BANKR. L.J. 197, 199-200 (1985) (observing that during the period from the date of filing until the date on which the debtor-in-possession assumes or rejects an executory contract, the non-debtor is bound to perform while the debtor-in-possession is temporarily not bound to perform). 
give the debtor greater contractual rights than it enjoys outside of bankruptcy. ${ }^{27}$

More precisely, section 365(e)(1) prohibits a party from terminating its contract with the debtor even if the contract contains an ipso facto (bankruptcy termination) clause that excuses the non-debtor from performing the agreement when the other party enters bankruptcy. ${ }^{28}$ It is therefore more accurate to say that bankruptcy does not affect the contract, regardless of the parties' agreements to the contrary. The precise rights and obligations of the parties are otherwise found in state contract law.

The debtor's agreements can be seen as partially outside of the estate, because the debtor must make the initial decision to either "reject" or "assume" each of its contracts and unexpired leases. ${ }^{29}$ If a debtor assumes a contract, the contract comes entirely into the estate and the debtor becomes bound by its terms. ${ }^{30}$ If a debtor "rejects" a contract the debtor commits a breach and the non-debtor party is left with a pre-petition claim for damages. ${ }^{31}$ The debtor's election essentially decides whether the contract will be treated as an asset or a claim.

In chapter 11, the debtor may generally assume or reject a contract at any time before the confirmation of a plan, or even under a plan. ${ }^{32}$ The court can order an earlier decision, or the counterparty can simply move to lift the automatic stay to allow it to proceed as it would outside of bankruptcy. ${ }^{33}$

Section 362 of the Bankruptcy code provides for relief from the automatic stay for "cause," including the lack of adequate protection of an interest in the property, something only applicable to secured creditors, or in instances where the debtor has no equity in the property and the property

27. See Hurley v. Atchison, Topeka \& Santa Fe Ry. Co., 213 U.S. 126, 134-35 (1909) (finding that the contract between debtor and debtee remained the same as before the bankruptcy).

28. See In re Triangle Laboratories, Inc., 663 F.2d 463, 465 (3d Cir. 1981) (finding that a bankruptcy termination clause to a contract that was made after the Bankruptcy Code became governing law was not enforceable).

29. 11 U.S.C. § 365(a). See also In re Qintex Entm’t, Inc., 950 F.2d 1492, 1495 (9th Cir. 1991) (observing that executory contracts contain "obligations of both parties that are so far unperformed that the failure of either party to complete performance would constitute material breach and thus excuse the performance of the other”); Streeter v. Sumner, 31 N.H. 542, 556-558 (1855) (stating that the assignee can choose which contracts to honor or repudiate if the contract will subject the estate to future losses).

30. 11 U.S.C. § 365(b)(1); Michael T. Andrew, Executory Contracts in Bankruptcy: Understanding "Rejection", 59 U. COLO. L. REV. 845, 846-47 (1988).

31. 11 U.S.C. § 365(g).

32. 11 U.S.C. $\S 365(d)(2)$.

33. See In re Nat'l Envtl Waste Corp., 191 B.R. 832, 834 (Bankr. C.D. Cal. 1996). Again, this assumes that the automatic stay is applicable, but most non-debtor parties are sufficiently risk adverse and thus will move to lift the stay in all cases. 
is not necessary for an effective reorganization. ${ }^{34}$ "Cause" is not defined by the Bankruptcy Code, but, as I argue in the next part of this paper, it should include those instances where the counterparty seeks to exercise its nonbankruptcy right of breach, subject to some assurance of the party's prompt payment of expectation damages. ${ }^{35}$

$* * *$

Derivatives are essentially outside of this system. ${ }^{36}$ Termination of a derivative is exempt from the automatic stay. ${ }^{37}$ Ipso facto clauses are enforceable in the derivative context. ${ }^{38}$ And termination of derivative contracts is expressly exempt from latter attack as either a constructive

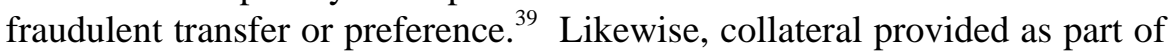
a derivative transaction may be foreclosed upon without concern that doing so violates the Bankruptcy Code. ${ }^{40}$

The 2005 amendments to the Bankruptcy Code enhanced this special treatment by adding section 561 that specifically preserves the contractual right to terminate, liquidate, accelerate or offset under a "master netting agreement" and across a broad range of derivative contracts. ${ }^{41}$ In addition, now a master agreement and several other derivative-related agreements can also be deemed "swap agreements" within the meaning of the Bankruptcy Code. ${ }^{42}$

Indeed, it seems that every derivative instrument qualifies as a "swap agreement" under the new amendments. ${ }^{43}$ Given that virtually every conceivable derivative transaction is now exempt from the automatic stay and the debtor's power to assume and reject, this seems like overkill. However, the industry plainly wanted to make it very clear that the bankruptcy court could not interfere with the normal, non-bankruptcy operations of the derivatives markets.

These specific provisions addressing master agreements are very

34. 11 U.S.C. § 362(d)

35. See, e.g., Hawkins v. McGee, 146 A. 641, 643 (N.H. 1929) (citing Davis v. New England Cotton Yarn Co., 92 A. 732, 733 (N.H. 1914)) ("By 'damages,' as that term is used in the law of contract, is intended compensation for a breach.").

36. Rhett Campbell, Financial Markets Contracts and BAPCPA, 79 AM. BANKR. L.J. 697, 712 (2005).

37. 11 U.S.C. $\S 560,561(a)$.

38. 11 U.S.C. $\S 560$.

39. 11 U.S.C. $\S \S 546(g), 548(d)(2)(D), 561(a)$. Arguably the 2005 amendments also limit the ability to bring an action for actual fraudulent transfers as well. Compare 11 U.S.C. §548(c), with 11 U.S.C. § 548(d)(2)(D).

40. 11 U.S.C. § 362(b)(17).

41. 11 U.S.C. $\S 561$.

42. 11 U.S.C. § 101(38A).

43. See Morrison \& Riegel, supra note 14, at 651-52 (explaining how the new amendments not only expand the list of protected swaps, but expand it to include nearly every contract traded in a derivative market). 
important because most of the derivatives in the global derivatives market are documented under International Swaps and Derivatives Association (ISDA) documentation. ${ }^{44}$ The ISDA Master Agreement, the most current version of which is the 2002 ISDA Master Agreement, is a standard agreement used in the industry to provide a set of default terms for a series of derivative transactions between a set of counterparties. A "schedule" is attached to the Master Agreement to account for party-specific terms of the deal. The economic terms of individual derivative transactions are reflected in "confirmation" term sheets, which are deemed to be part of the single Master Agreement between the parties, somewhat like the schedules of equipment used in long-term equipment leases. Each confirmation will incorporate by reference a relevant set of ISDA definitions. The effect of the new amendment to the Bankruptcy Code is to bless this approach to derivatives and protect them from the claim, common in the equipment leasing context, that each schedule constitutes a separate contract that can be assumed or rejected by debtor.

\section{REJECTION AND THE OPTION TO BREACH}

It has long been settled that the default remedy for breach of contract is an award of expectation damages. ${ }^{45}$ The purpose of this remedy is to put the non-breaching party in "as good a position as he would have been had the" contract been performed. ${ }^{46}$ Punitive damages are rarely awarded, usually limited to situations in which the breach of a contract would also constitute an independent tort. ${ }^{47}$ The equitable remedy of specific performance, which is awarded more often than punitive damages, is also quite limited. ${ }^{48}$ In fact, specific performance will not be awarded unless the award of expectation damages would be inadequate to make the non-breaching party whole. ${ }^{49}$

44. Robert F. Schwartz, Risk Distribution In The Capital Markets: Credit Default Swaps, Insurance And A Theory Of Demarcation, 12 FordHAM J. CORP. \& Fin. L. 167, 17879 (2007).

45. Robert L. Birmingham, Breach of Contract, Damage Measures, and Economic Efficiency, 24 RutGERs L. REV. 273, 281 (1970).

46. Id.

47. William S. Dodge, The Case for Punitive Damages in Contracts, 48 DuKE L.J. 629, 636 (1999); see also Clark A. Remington, Intentional Interference with Contract and the Doctrine of Efficient Breach: Fine Tuning the Notion of the Contract Breacher as Wrongdoer, 47 BufF. L. REV. 645 (1999) (arguing that courts should only punish interference that leads to a wrongful breach).

48. Melvin A. Eisenberg, Actual and Virtual Specific Performance, The Theory of Efficient Breach, and the Indifference Principle in Contract Law, 93 CAL. L. REV. 975, 1016 (2005).

49. E. Allan Farnsworth, Farnsworth On CONTRACTS § 12.6 (3d ed. 2004); see also John P. Dawson, Restitution or Damages?, 20 OHIO ST. L.J. 175 (1959) (characterizing 
For a long time, contractual remedies were justified on moral grounds. ${ }^{50}$ A contract involves a promise by one party to perform some act in exchange for a promise by the other party to do another act and the failure to fulfill one's promise was seen as morally blameworthy. ${ }^{51}$ Therefore, "a properly organized society should not tolerate" a failure to perform as promised. ${ }^{52}$

But in the business context, the morality of most contracting parties is at most derivative of the morality of the actor's agents, given that the actors are typically artificial "persons" created by state corporate statutes. ${ }^{53}$ Moreover, if the failure to keep a promise is morally blameworthy, why are punitive damages not recoverable ${ }^{54}$ Why are the damages limited to those that put the non-breaching party in the position he would have been in had the contract been performed?

For similar reasons, Holmes explained that "the duty to keep a contract at common law means a prediction that you must pay damages if you do not keep it, - and nothing else." ${ }^{55}$ That is, a contract is better viewed as a choice between fulfilling a promise or breaching and paying damages. ${ }^{56}$ To be sure, in certain extreme instances the law of restitution creates a conflict with this conception of contracts, but in the vast run of cases Holmes' conception remains accurate. ${ }^{57}$

the major types of restitution remedies and their interaction with damage remedies in cases of substantial breach).

50. Birmingham, supra note 45, at 281; see also Steven Shavell, Is Breach of Contract Immoral?, 56 EMORY L. J. 439 (2006) (questioning whether breaching a contract is immoral if there is no contingency provision in the contract).

51. Shavell, supra note 50 at 439 .

52. Birmingham, supra note 45, at 281 (quoting Morris R. Cohen, The Basis of Contract, 46 HARV. L. REV. 553, 571-72 (1933)).

53. Cf. Lewis A. Kornhauser, An Introduction to the Economic Analysis of Contract Remedies, 57 U. CoLO. L. REv. 683, 685-86 (1986) (discussing how an economic analysis of contract law rejects the view of a contract as a promise but rather as a means of promoting efficiency).

54. See Birmingham, supra note 45, at 284 (explaining that penalizing efficient breach by overcompensating the innocent party would discourage efficient reallocation of community resources).

55. Oliver Wendell Holmes, Jr., The Path of the Law, 10 HARV. L. REv. 457, 462 (1897). But see Joseph M. Perillo, Misreading Oliver Wendell Holmes on Efficient Breach and Tortious Interference, 68 FordHAM L. REV. 1085 (2000) (linking the concept of efficient breach to the misunderstanding of Holmes' theory).

56. I make no claims in this paper about whether this reality is socially efficient. See generally Eric A. Posner, Economic Analysis of Contract Law After Three Decades: Success or Failure?, 112 YALE L.J. 829, 834-38 (2002-2003)(explaining that a justification for expectation damages, that performance of the contract occurs if and only if it is efficient, is premature).

57. See Restatement (ThiRd), Restitution And UnJust EnRichment § 39 (Tentative Draft No. 4, 2005) (providing for restitution for breaches that are "both material and opportunistic”); see also J. Rogers, Restitution for Wrongs and the Restatement (Third) of 
Section 365 of the Bankruptcy Code can then be seen as an extension of the classic concept of expectation damages and the more recent understandings of the option to breach. Upon entering bankruptcy a debtor-firm examines its contracts and decides which ones have a negative net present value. The debtor breaches these contracts, by rejecting them under section 365, and assumes the contracts that are valuable.

Seen in this light, section 365 loses much of rhetorical power-it no longer performs any "magic," it simply allows the debtor to do what it can always do outside of bankruptcy. An insolvent corporate debtor's incentives with regard to the breach decision are skewed by the reality that the decision to breach does not impose additional costs on the firm. Instead, because an insolvent debtor's unencumbered assets are finite, the decision to breach a contract reallocates wealth among the unsecured creditors. But this is not the product of any bankruptcy system, but instead it is the result of the combined effects of insolvency and limited liability. ${ }^{58}$

Indeed, outside of bankruptcy an insolvent firm has an incentive to breach every contract that is unprofitable, not simply those contracts whose breach can be termed "efficient." 59 For example, assume Bogartco, Inc. signs a contract to produce fedoras for a department store at $\$ 10$ per unit, and material costs rise so that it now costs $\$ 12$ per unit to manufacture the hats. ${ }^{60}$ If Bogartco is solvent, it will not breach under these facts because doing so is not profitable: assuming that material costs are not specific to Bogartco, the department store will pay \$12 per unit to cover Bogartco's breach, and Bogartco will pay $\$ 2$ per unit in expectation damages. ${ }^{61}$ But if

the Law of Restitution, 42 WAKE FOREST L. REV. 55, 66-67 (2007) (explaining that in many instances, restitution provides a means of recovery for acts described as wrongful in other areas of the law). By its own terms, the new restatement instructs that contract damages "are ordinarily an adequate remedy if they can be used to acquire a full equivalent to the promised performance in a substitute transaction.” RESTATEMENT (THIRD), RESTITUTION AND UNJUST ENRICHMENT $\S 39$ (Tentative Draft No. 4, 2005). That is, restitution is not available when the non-breaching party can "cover," even if the breaching party profits from the breach. Id. This is illustrated further in my "Bogartco" example. See infra p.112.

58. See Henry Hansmann \& Reinier Kraakman, Toward Unlimited Shareholder Liability for Corporate Torts, 100 YALE L.J. 1879 (1991) (arguing against shareholder limited liability where plaintiff is a tort victim).

59. See Westbrook, supra note 9, at 254-55; cf. Melvin A. Eisenberg, Actual and Virtual Specific Performance, the Theory of Efficient Breach, and the Indifference Principle in Contract Law, 93 CAL. L. REV. 975, 997 (2000) (explaining that breaching a contract is efficient and thus desirable when one party's gain from breaching, after payment of expectation damages, outweighs the non-breaching party's loss from the breach).

60. See David W. Barnes, The Anatomy of Contract Damages and Efficient Breach Theory, 6 S. CAL. INTERDISC. L.J. 397, 408-412 (1998) (explaining that despite its simplicity in certain contexts, there are frequently more complex cases where it is difficult to ascertain whether a breach is efficient).

61. I am obviously assuming that Bogartco is unable to exploit the transaction costs of enforcement and other damage rules that limit the department store's recovery in the real 
Bogartco is insolvent it will breach the contract, since the expectation damages will simply expand the size of the total claims asserted against its unencumbered assets and the firm is presumably indifferent as to the distribution of its assets among its creditors.

The Bankruptcy Code does not change this calculation, as the power to reject under section 365 is precisely the same as the power to breach while insolvent. ${ }^{62}$ The "cherry picking" argument then loses much of its force -- rejection is the equivalent of breach, and assumption quo assumption is simply a decision to perform under the contract. ${ }^{63}$

This story does not change when viewed from the non-debtor side of the contract. Upon a counterparty's bankruptcy, the non-debtor party can choose to continue to perform or to breach. If the latter course is chosen, the non-debtor will most likely seek court approval, which will involve showing that there is "cause" to lift the automatic stay and allow breach of

world. These issues are especially likely to influence the parties when the damages are small relative to the potential transaction costs, such as in my example. For more on these issues, see Charles J. Goetz \& Robert E. Scott, Liquidated Damages, Penalties and the Just Compensation Principle: Some Notes on An Enforcement Model and A Theory of Efficient Breach, 77 Colum. L. REv. 554 (1977) (hypothesizing that a liquidated damages provision is in many circumstances the most efficient means by which contracting parties can insure against consequences of a breach that are not easily quantifiable); Ian R. Macneil, Efficient Breach of Contract: Circles in the Sky, 68 VA. L. REV. 947 (1982) (examining the fallacy in the so-called "simple-efficient-breach analysis"); Alan Schwartz, The Case for Specific Performance, 89 YALE L.J. 271 (1979) (arguing that specific performance as a remedy should be as routinely available as damages); see also Thomas D. Morgan \& Robert W. Tuttle, Legal Representation in a Pluralist Society, 63 GEO. WASH. L. REV. 984, 984 (1995) (acknowledging a paradox that arises when rival visions of the good life conflict due to the absence of a comprehensive doctrine of the good life that would encompass each party's conception).

62. On this point I depart slightly from Professor Westbrook's otherwise brilliant explication of section 365, inasmuch as he ties section 365 to the ability to pay breach claims at an amount less than the face value of the claim. Westbrook, supra note 9, at 25355. My conception of contracts, at least in a corporate bankruptcy setting, may also be closer to "Holmes and Posner" than to Professor Westbrook's. Westbrook, supra note 9, at 280 ("Whether Posner and Holmes like it or not, promise-breaking has a moral dimension . . . . In part, the grant in section 365 of the right of assumption and rejection may reflect the need to give the trustee the moral right to breach a contract. The trustee's moral position is sound, because it is acting for the innocent unsecured creditors, not for the deadbeat debtor.”).

63. Section 365 does differ from state contract law on one point, but it is not clear that this difference provides any support to the cherry picking argument. Specifically, under state law a contract term may prevent or restrict a party from assigning its rights under that contract, but Bankruptcy Code section 365(f)(1) states that a debtor may assume and assign an executory contract or unexpired lease "notwithstanding a provision in [the] executory contract or unexpired lease of the debtor, or in applicable law, that prohibits, restricts, or conditions the assignment of such contract or lease.” 11 U.S.C. § 365. This provision results in a wealth transfer from the non-debtor party to the unsecured creditors generally, but it does result in any special benefit to the debtor. 
the contract. ${ }^{64}$ But upon the non-debtor's demonstration of its willingness and ability to pay expectation damages, there does not seem to be any good reason for a court to deny the motion. Although courts sometimes assert the ability to order the non-debtor party to perform a contract, ${ }^{65} \mathrm{I}$ take this to mean that the non-debtor party must either perform or pay full breach damages to the debtor. ${ }^{66}$ The bankruptcy courts' general history in equitywhich tends to be oversold in any event ${ }^{67}$ — should not be read to include an ability to afford specific performance in instances where it would not be available outside of bankruptcy. ${ }^{68}$

Often a debtor will incur substantial costs to cover the breached contract, given the risk premium most counterparties will extract as a result of the debtor's financial condition. ${ }^{69}$ In many instances the high costs of cover-which will translate into large breach damages-will render the breach costs prohibitive, but this does not alter the fundamental option to breach.

This also explains the Bankruptcy Code's general prohibition on ipso facto clauses. ${ }^{70}$ Initially, it must be acknowledged that section 365(e) is an under-theorized area of the Bankruptcy Code. ${ }^{71}$ The leading treatise unhelpfully explains that "[s]ection 365(e) expressly invalidates ipso facto and other bankruptcy termination clauses that might otherwise prevent the estate from receiving the benefit of an executory contract or lease." ${ }^{, 72}$ To the extent this is an attempt to justify the provision based on the gains to the debtor, the analysis is rather vacuous. It is easy to imagine a good number of provisions that could be created if the sole aim is to transfer

64. See In re El Paso Refinery, L.P., 220 B.R. 37, 43-44 (W.D. Tex. 1998) (stating that the "relief from stay" option is not a true alternative to the choice framed by section 365 because at the hearing on such a motion, the non-debtor party must establish "cause" for relief from stay).

65. In re Continental Energy Assoc. Ltd., 178 B.R. 405 (Bankr. M.D. Pa. 1995); see also Schwartz, supra note 1, at 1231 ("[A]n insolvent firm that has entered bankruptcy may 'assume' an ongoing contract and thereby require the solvent firm to perform it.”).

66. See U.C.C. § 2-713 (defining buyer’s damages for non-delivery or repudiation).

67. 1 James Kent, COMMENTARIES ON AMERICAN LAW 382 (6th ed. 1848) ("This [bankruptcy] jurisdiction of the English chancellor is not in the court of chancery, but in the individual who holds the great seal.”).

68. See Adam J. Levitin, Toward a Federal Common Law of Bankruptcy: Judicial Lawmaking in a Statutory Regime, 80 AM. BANKR. L.J. 1 (2006) (explaining a bankruptcy court's role as a court of equity).

69. See U.C.C. § 2-712 (explaining a buyer’s right to cover).

70. Clauses that allow automatic termination of contracts upon one party's bankruptcy.

71. Professor Schwartz argues that ipso facto clauses are "a perfect substitute for accurate expectation damages," that guard against judicial errors in calculating such damages. Schwartz, supra note 1, at 1234. It seems odd that the parties would embed such protection in a clause that is only triggered upon bankruptcy or insolvency.

72. 3 Collier On BANKRUPtCy, \ 365.07 (Alan N. Resnick \& Henry J. Sommers eds., 15th ed. rev. 2006). 
value to the debtor to facilitate its reorganization. A provision forfeiting employee pensions to the debtor would pass this test, but who would support such a move?

More convincingly, section 365(e) can be seen as a prohibition on inefficient breach. Termination based on the non-debtor's general fear of bankruptcy, refusal to deal with "deadbeats," or other idiosyncratic reasons are disallowed, unless the party in question is willing to pay breach damages to the debtor. ${ }^{73}$ The non-debtor's willingness to pay breach damages limits terminations to those that are socially efficient. ${ }^{74}$ Or, stated otherwise, limiting breaches to those situations where the non-debtor party is willing to pay damages is consistent with the Bankruptcy Code's attempt to treat contracts as though the bankruptcy never happened. ${ }^{75}$

$* * *$

Thus re-conceptualized, the special treatment of derivatives becomes theoretically suspect, especially when based on arguments about "cherry picking” of contracts. But the delay that the Bankruptcy Code imposes on the parties' breach option could be significant in the case of a financial firm in bankruptcy. For this reason I do not argue for the complete repeal of the Bankruptcy Code's special derivative provisions. But before addressing this point, I first address the argument that the special treatment of derivatives can be justified by their lack of going concern value.

\section{THE GOING CONCERN VALUE OF DERIVATIVES \& THE LIMITS OF SPECIAL TREATMENT}

Derivatives are contracts that derive their value from interest rates, the outcome of specific events, or the price of underlying assets such as debt or equities. $^{76}$ Options, futures, and forwards are all long-recognized types of derivatives. ${ }^{77}$

73. Section 365(e) also prohibits using ipso facto clauses as a kind of cross default provision, that would allow cancellation of all contracts, whether or not doing so would be socially efficient. In short, 365(e) prohibits the kind of cross netting that the Bankruptcy Code’s new derivative provisions expressly allow. 11 U.S.C. §§546(g), 548(d)(2)(D), 561(a).

74. Cf. Thomas E. Plank, Bankruptcy and Federalism, 71 FordHAM L. Rev. 1063, 1127-28 (2002) (describing situations under the Non-Interference and Non-Expropriation principles where either the bankruptcy trustee or the non-debtor must continue to perform under the contract).

75. See Hurley v. Atchison, Topeka \& Santa Fe Ry. Co., 213 U.S. 126, 134-135 (1909) (holding that the equitable rights of the parties were not changed by the commencement of bankruptcy proceedings and thus all obligations of a legal and equitable nature remained unchanged).

76. Allen, Brealey \& Myers, supra note 4, at 727.

77. See, e.g., Adolf A. Berle, JR., StUdies in the LaW of Corporation FinanCe 133 (1928) (stating that it is well founded that "the privilege granted to the holder of a 
The heart of the modern derivatives markets was born in the early 1980s with the advent of swap agreements. ${ }^{78}$ One of the most common swaps is an interest rate swap, where the parties (or "counterparties") agree to exchange a fixed rate cash flow for a floating rate cash flow. ${ }^{79}$ The amount of the cash flows is determined by reference to a hypothetical or "notional" amount of money that is never actually exchanged between the parties. $^{80}$ Similar swaps can be written on currency fluctuations or commodity prices. These swaps and other derivatives can be used for either speculation or to hedge against future changes in the prices of underlying rate or commodity. ${ }^{81}$

Financial firms and pension funds are the most obvious speculative users of derivatives, but corporations also use derivatives and the vast majority of those users do so for hedging purposes. ${ }^{82}$ Derivatives here are used for the simple purpose of avoiding the adverse effects of future spikes in the price of a needed commodity or sudden change in the value of the payments the corporation receives from sales abroad.

Thus, Owens Corning, a manufacturer of building materials, reports in its $200610-\mathrm{K}$ that it uses derivatives to hedge "certain energy and energy related exposures on a rolling forward basis up to 36 months out." 83 And the Union Pacific Corporation, operator of one of the country's largest railroads, likewise reports that it uses derivatives "to assist in managing ... . overall exposure to fluctuations in interest rates and fuel prices ... [Union Pacific does] not use derivative financial instruments for speculative purposes." 84

General Motors Corporation's 2006 annual report notes extensive use of derivatives for hedging, explaining that "[r]ecently, the global

convertible obligation to require stock at his election instead of money in payment of the debt evidenced by the instrument is an option"); Frank Partnoy, The Shifting Contours of Global Derivatives Regulation 22 U. PA. J. INT'L ECON. L. 421, 424-28 (2001) (explaining the difference between options and forwards as classes of derivatives).

78. See Bank One Corp. v. Comm'r, 120 T.C. 174, 186-87 (2003) ("The origin of the swaps market is generally traced to a currency swap negotiated between the World Bank and IBM in 1981. That transaction involved an exchange of payments in Swiss francs for payments in deutschmarks. The first interest rate swap was negotiated with the Student Loan Marketing Association in 1982.”).

79. Allen, Brealey \& Myers, supra note 4, at 735-37; Louis Vitale, Comment, Interest Rate Swaps under the Commodity Exchange Act, 51 CASE W. RES. L. REv. 539, 547-59 (2001).

80. Thrifty Oil Co. v. Bank of Am. Nat'l Trust, 322 F.3d 1039, 1042 (9th Cir. 2003).

81. See Robert J. Aalberts \& Percy S. Poon, Derivatives and the Modern Prudent Investor Rule: Too Risky or Too Necessary?, 67 Оніо ST. L.J. 525, $552-53$ (2006) (explaining how derivatives can be used either to speculate or to hedge).

82. Henk Berkman \& Michael E. Bradbury, Empirical Evidence on the Corporate Use of Derivatives, 25 Fin. MANG. 5 (1996).

83. Owens Corning, Annual Report (Form 10-K), at 53 (Mar. 14, 2007).

84. Union Pacific, Annual Report (Form 10-K), at 34 (Feb. 23, 2007). 
automotive industry has experienced increases in commodity costs, most notably for raw materials such as aluminum, copper, and precious metals . . .. [GM] attempt[s] to manage...fluctuations in commodity prices by using derivatives to economically hedge a portion of raw material purchases." ${ }^{85}$ And later noting that "GM has foreign currency exposures related to buying, selling, and financing in currencies other than the local currencies in which it operates. Derivative instruments, such as foreign currency forwards, swaps, and options are used to hedge these exposures."86

If any of these firms enter chapter 11-Owens Corning recently left chapter 11, while GM recently filed, so the argument is not purely hypothetical - these derivative contracts could be an integral part of the firm's going concern value. For example, given the recent weakness in the U.S. dollar, currency swaps may save a firm from incurring significant losses on contracts with foreign suppliers.

With this understanding of the role of derivatives in modern business, it is hard to accept the blanket argument that derivatives are not firm specific assets, and thus do not contribute to a firm's going concern value. ${ }^{87}$ Rather, in the chapter 11 case of any large non-financial firm, the Bankruptcy Code's provisions allowing for the termination of swaps and other derivatives upon bankruptcy are inconsistent with the central goal of maximizing the value of the debtor's estate. ${ }^{88}$ Indeed, they represent little more than a wealth transfer to the financial institutions that stand on the other side of these swaps.

Moreover, it is not clear why the Bankruptcy Code should adopt this sort of "one size fits all” approach to derivatives. In the Tax Code, it has long been recognized that a corporation's investments in financial instruments can exist for the purpose of speculation or hedging. ${ }^{89}$ In the first case, the instrument is treated as a capital asset; in the second case the hedge is treated as part of the firm's normal business operations. ${ }^{90}$ The difference between ordinary loss and capital loss tax treatment is significant. Under the Tax Code, corporate capital losses can only be deducted against capital gains in the corporation's computation of its income for federal income tax, while the corporation can offset ordinary

85. General Motors, Annual Report (Form 10-K), at 7 (Mar. 13, 2007).

86. Id. at 94 .

87. Edwards \& Morrison, supra note 7.

88. See Frank Partnoy \& David A. Skeel, The Promise and Perils of Credit Derivatives, 75 U. Cin. L. REV. 1019, 1050 (2007) (noting that these "blanket rules" invite strategic termination by non-debtors).

89. Corn Prods. Ref. Co. v. Comm'r, 350 U.S. 46, 52 (1955); see Paul M. Schmidt, The Hedging Rules: Clarity or Confusion?, 72 TAX NOTES 1169 (1996) (discussing the IRS's recognition of financial instruments' roles as hedging transactions).

90. 26 U.S.C. $\S \S 1221(\mathrm{a})(7), 1221(\mathrm{~b})(2)$; Treas. Reg $\S 1.1221-2(\mathrm{~b})$ (disallowing hedging transactions from the IRS’s “capital asset” definition). 
losses against all income. ${ }^{91}$ Corporations, as a general rule, have a larger amount of ordinary income than capital gains. The Bankruptcy Code could presumably draw similar distinctions, as I suggest below.

To be sure, this does not mean that the Bankruptcy Code's derivatives provisions are always unwarranted, but rather that they are just overbroad. It also bears noting that there may be non-domestic reasons for urging a broad, arguably excessively broad, exemption of derivatives from the core provisions of the Bankruptcy Code. In particular, other jurisdictions may operate corporate reorganization systems that are inefficient or opaque in comparison to chapter 11. Broad exemption provisions may be warranted in these jurisdictions, and the derivatives industry may find it useful to note that important European and North American jurisdictions also follow such a course. ${ }^{92}$ But it hardly seems appropriate or sensible to endure tinkering with the Bankruptcy Code just to support an international sales pitch. ${ }^{93}$

Once we acknowledge that derivatives are used for two distinct purposes, the Bankruptcy Code's focus on financial debtors becomes quite puzzling, given that financial firms clearly do not make up the bulk of chapter 11 cases. As Professors Partnoy and Skeel have argued, "the blanket exception for derivatives should be rethought." 94

The foregoing has made the case that the Bankruptcy Code's special derivatives provisions are overbroad as applied to non-financial firms in chapter 11 . That leaves two categories of firms for which the special provisions might still have merit: firms that liquidate under chapter 7 and financial firms that file under either chapter 7 or 11.

Firms that file under chapter 7 declare their intention to liquidate and

91. See Circle K Corp. v. United States, 23 Cl. Ct. 665 (1991); see also Fed. Nat'l Mortgage Ass'n v. Comm'r, 100 T.C. 541, 569 (1993) (noting that hedges exist primarily to guard against risks in future price fluctuations).

92. See, e.g., Letter from Dr. Peter M Werner, Director of Policy, International Swaps and Derivatives Association, to Arman Galiaskarovich Dunayev, Chairman Agency of the Republic of Kazakhstan for the Regulation and Supervision of the Financial Market and Financial Organisations, (Apr. 15, 2007) (on file with author) (discussing the need for new legislation to clarify "the legal enforceability of the ISDA Master Agreement and in particular, close-out netting in Kazakhstan and thereby foster greater harmonization of international standards.”).

93. Adoption of these provisions by the United States also compels adoption of comparable provisions in jurisdictions that engage in regulatory competition with the United States. Stephanie Ben-Ishai \& Peter Kolla, Derivatives and the CCAA, in CANADIAN BANKRUPTCY \& INSOLVENCY LAW 47, 55-56 (Stephanie Ben-Ishai \& Anthony Dugan eds., 2007).

94. Partnoy \& Skeel, supra note 88, at 1050 (“Although a more fine-grained approach that applied the automatic stay to some derivatives, such as those designed for insurance purposes, would complicate the treatment of derivatives in bankruptcy, we believe that a more nuanced approach is preferable to adopting a blanket rule that invites strategic termination by non-debtors.”). 
likely destroy any chance at even a sale as a going concern. ${ }^{95}$ Seen in that light, it is hard to argue that such firms have any going concern value in their derivatives. Moreover, given the party-specific nature of many of these transactions, particularly when used as hedges, there may be reasons to preclude their assignment to non-debtor parties - just as loans and insurance contracts are similarly not assignable. ${ }^{96}$ If non-assignable, there is no reason for the liquidating firm to keep derivative contracts in the estate, and the special treatment of derivatives is not objectionable.

The treatment of financial firms is somewhat more problematic. The derivatives industry has generally justified the special treatment of derivatives as justified by the need "to protect markets . . . particularly vital and sensitive to the delay and dislocation that can attach to bankruptcy proceedings." ${ }^{\text {97 }}$ Although arguably the lack of an automatic stay to give the markets time to gather information could lead to panic and financial contagion, ${ }^{98}$ the industry argument, if accepted, has the most weight in the case of financial firms, with large derivative portfolios. The generally speculative nature of the portfolios also argues against any going concern value, and in favor of exclusion from the estate. ${ }^{99}$

Accordingly, the special treatment of derivatives is most justified in chapter 7 cases and all types of cases involving financial firms. In chapter 11 cases of non-financial firms, on the other hand, there is no reason why derivatives should not be treated like any other contractual asset of the estate.

These are simply rules of thumb, and thus I argue for a set of rebuttable presumptions corresponding with these two classes of bankruptcy cases. The special rules for derivatives should be presumed to apply only in chapter 7 and financial firm bankruptcy cases. And conversely, the special rules should be presumed inapplicable in the chapter 11 cases of traditional, non-financial, debtors. Any party in interest could move to rebut the presumptions.

While it is certainly arguable that this approach does not go far enough, ${ }^{100}$ it retains the special derivative treatment for those cases where such treatment is arguably most appropriate, while limiting the extreme overreaching of the 2005 amendments as currently enacted.

95. Stephen J. Lubben, Business Liquidation, 81 Am. BANKR. L.J. 65, 69 (2007).

96. 11 U.S.C. § 365(c).

97. Brief for International Swaps And Derivatives Association, Inc. as Amicus Curiae Supporting Respondents, 7, Hutson v. E.I. Dupont De Nemours (In re Nat'l Gas Distrib.), 556 F.3d 247 (3d Cir. 2009) (No. 07-2105), 2008 U.S. 4th Cir. Briefs LEXIS 63, **7 (original on file with author).

98. Edwards \& Morrison, supra note 7, at 103-04; Partnoy \& Skeel, supra note 88, at 1050.

99. Edwards \& Morrison, supra note 7, at 114-16.

100. Supra note 13. 


\section{CONCLUSION}

This Article makes three main claims. First, the ability to assume and reject contracts under the Bankruptcy Code is not particularly special, and simply reflects the general option to breach and pay damages that exists under non-bankruptcy contract law. Second, the use of derivatives for hedging is distinct from the use for speculation, and when used for hedging, derivatives are like other contractual assets. And third, the special treatment of derivatives under the Bankruptcy Code is overbroad because it fails to acknowledge this distinction. Reframing the special derivative provisions as rules that could apply to a case under a set of presumptions would return these provisions to a more logical, justifiable scope and thus represents a first step in rationalizing what otherwise seems to be a clear case of overreaching by special interests. 